\title{
Pengaruh Samsat Keliling, Samsat Drive-Thru, E-Samsat Terhadap Penerimaan Pajak Kendaraan Bermotor Pada Kantor Samsat Jakarta Timur
}

\author{
Hartanti ${ }^{1, *}$, Rr Karina Alviani ${ }^{2}$,Ratiyah ${ }^{3}$ \\ ${ }^{1}$ Manajemen Pajak; Universitas Bina Sarana Informatika; Jl.Kamal Raya no. 18, \\ Ringroad Barat Cengkareng Jakarta;Telp.021-5437639; e-mail: hartanti.hti@bsi.ac.id \\ 2 Manajemen Pajak; Universitas Bina Sarana Informatika; Jl.Kamal Raya no. 18, \\ Ringroad Barat Cengkareng Jakarta;Telp.021-5437639; e-mail: \\ rr.karinaalviani@gmail.com \\ 3 Manajemen Pajak; Universitas Bina Sarana Informatika; Jl.Kamal Raya no. 18, \\ Ringroad Barat Cengkareng Jakarta;Telp.021-5437639; e-mail: ratiyah.rty@ bsi.ac.id \\ * Korespondensi: e-mail: hartanti.hti@bsi.ac.id
}

Diterima: 01 Mei 2020; Review: 04 Mei 2020; Disetujui: 18 Juni 2020

Cara sitasi: Hartanti, Alviani K rr, Ratiyah. 2020. Pengaruh Samsat Keliling, Samsat Drive-Thru dan E-Samsat Terhadap Penerimaan Pajak Kendaraan Bermotor Pada Kantor Samsat Jakarta Timur. Jurnal Online Insan Akuntan. Vol. 5 (1): 125-136.

\begin{abstract}
Abstrak: Pajak kendaraan bermotor termasuk pajak daerah yang dikelola oleh pemerintah tingkat satu atau provinsi. Dalam mengelola pajak kendaraan bermotor, pemerintah daerah mendirikan Kantor Samsat dimana kantor tersebut memberikan bermacam-macam layanan seperti Samsat Keliling, Samsat Drive Thru dan E-Samsat. Penelitian ini bertujuan untuk mengetahui pengaruh secara parsial maupun simultan Penerimaan Pajak dari Samsat keliling, Samsat Drive Thru dan E-Samsat terhadap penerimaan pajak kendaraan bermotor di Jakarta Timur. Metode analisis menggunakan metode Diskriptif Kuantitatif dan di analisis menggunakan regresi linier berganda. Hasil penelitian menunjukkan secara parsial Samsat Drive Thru berpengaruh signifikan terhadap penerimaan pajak kendaraan bermotor, sedangkan Samsat keliling dan E-Samsat secara parsial tidak berpengaruh terhadap penerimaan Pajak kendaraan bermotor pada Kantor Samsat Jakarta Timur. Secara Simultan Samsat Keliling, Samsat Drive Thru, E-Samsat berpengaruh terhadap penerimaan pajak kendaraan bermotor pada Kantor Samsat Jakarta Timur
\end{abstract}

Kata kunci: Samsat keliling, Samsat Drive-Thru, E-Samsat, Pajak kendaraan Bermotor

\begin{abstract}
The motor vehicle tax includes local taxes which are managed by the first or provincial level government. In managing the motor vehicle tax, the local government established the Samsat Office where the office provided various services such as the Mobile Samsat, the Samsat Drive Thru and the ESamsat. This study aims to determine the effect of partial or simultaneous tax receipts from mobile Samsat, Samsat Drive Thru and E-Samsat on motor vehicle tax in East Jakarta. The analysis method uses quantitative descriptive method and analyzed using multiple linear regression. The results showed partially Samsat Drive Thru had a significant effect on motor vehicle tax revenue, while mobile Samsat and E-Samsat partially had no effect on motor vehicle tax receipts in the East Jakarta area. Simultaneously Samsat Keliling, Samsat Drive Thru, E-Samsat affect the tax revenue of motor vehicles in the area samsat of East Jakarta
\end{abstract}

Keywords: Mobile Samsat, Samsat Drive-Thru, E-Samsat, Motorized Vehicle Tax 


\section{Pendahuluan}

Diera modernisasi masyarakat dalam beraktivitas berpindah-pindah tempat membutuhkan moda transportasi, salah satunya berupa kendaraan bermotor. Dikota besar seperti Jakarta, kepemilikan akan kendaraan bermotor sangatlah tinggi, hal ini didukung dari lembaga finance yang memberikan kemudahan masyarakat untuk memiliki kendaraan bermotor. Berdasarkan data statistik kepemilikan kendaraan bermotor di wilayah Jakarta rata-rata diatas pertahun 5,35 \% di tahun 2012-2016, dengan kepemilikan kendaraan bermotor yang sangat tinggi diharapkan dapat mendorong peningkatan penerimaan pajak daerah dari masyarakat yang membayar pajak kendaraan bermotor.

Menurut Pasal 1 angka 12 dan 13 (Undang-Undang Republik Indonesia Nomor 28, 2009), Pajak Kendaraan Bermotor adalah pajak atas kepemilikan dan/atau penguasaan kendaraan bermotor. Kendaraan bermotor adalah semua kendaraan beroda berserta gandengannya yang digunakan di semua jenis jalan darat, dan digerakkan oleh peralatan teknik berupa motor atau peralatan lainnya yang berpungsi untuk mengubah suatu sumber daya energi tertentu menjadi tenaga bergerak kendaraan bermotor yang bersangkutan, termasuk alat berat dan alat besar yang dalam operasinya mengunakan roda dan motor yang tidak melekat secara permanen serta kendaran bermotor yang dioperasikan di air. Pajak kendaraan bermotor menurut Undang-undang peraturan daerah No.28 tahun 2009, merupakan salah satu jenis pajak yang memberikan kontribusi terhadap penerimaan pajak daerah. Penerimaan pajak kendaraan bermotor di laporkan dalam Anggaran Belanja Daerah provinsi, yang digunakan untuk membiayai pengeluaran daerah Pajak kendaraan bermotor dibayarkan oleh masyarakat pemilik kendaraan bermotor setiap tahun. Pembayaran dapat dilakukan melalui kantor bersama SAMSAT yang dibentuk oleh pemerintah daerah disetiap wilayah.

(Peraturan Presiden Republik Indonesia Nomor 5, 2015) Pelayanan yang dilakukan Kantor Bersama SAMSAT yaitu dengan membentuk unit SAMSAT pembantu, SAMSAT gerai atau corner atau payment point atau outlet, SAMSAT Drive-Thru, SAMSAT Keliling, SAMSAT delivery order atau door to door, ESAMSAT, dan pengembangan SAMSAT. Pelayanan tersebut diharapkan mampu meningkatkan meningkatkan penerimaan pajak bermotor khususnya penerimaan di 
Kantor SAMSAT Kantor Samsat Jakarta Timur. Pelayanan ini memberikan kesempatan kepada Pemilik kendaraan untuk memilih jenis pelayanan yang lebih efektif dan efisien.

\section{Samsat Keliling}

(Peraturan Presiden Republik Indonesia Nomor 5, 2015) Pelayanan tentang penyelenggaraan sistem administrasi manunggal satu atap kendaraan bermotor salah satu jenis pelayanannya adalah dengan SAMSAT Keliling dimana samsat keliling ini melayani layanan pengesahan STNK, pembayaran PKB dan SWKLLJ dengan menggunakan kendaraan bermotor yang beroperasi dari satu tempat ke tempat lainnya.

Penelitian [Rohemah et al., 2016] menyatakan bahwa" Layanan Samsat keliling akses dan complain center berpengaruh terhadap kepatuhan wajib pajak, sedangkan fasilitas dan website tidak berpengaruh terhadap kepatuhan wajib pajak.

\section{Drive Thru}

[Mawardi, 2011] sistem dari pelayanan Drive Thru ini diadopsi dari pelayanan yang dilakukan oleh restoran makanan cepat saji, seperti Kentucky Fried Chicken dan McDonalds. Drive Thru sendiri berasal dari kata drive through yang artinya lewat kemudi di mana penyediaan fasilitas tersebut memungkinkan pelanggan atau wajib pajak tidak perlu turun mobil dalam mendapatkan pelayanan.

[Waqidah, 2017] dukungan teknologi informasi dapat mempercepat proses pelayanan dan pemeriksaan. Hal ini merupakan salah satu bentuk dari modernisasi pajak. Drive-Thru adalah bentuk pelayanan pengesahan STNK setiap tahun, pembayaran Pajak Kendaraan Bermotor (PKB) dan Sumbangan Wajib Dana Kecelakaan Lalu Lintas Jalan (SWDKLLJ) yang tempat pelaksanaannya diluar gedung Kantor Bersama SAMSAT dan memungkinkan Wajib Pajak melakukan transaksi tanpa harus turun dari kendaraan bermotor yang dikendarainya. Penelitian dari Waqiah (2017) menunjukkan bahwa "layanan drive thru memberikan kontribusi yang besar terhadap pendapatan Asli Daerah Madiun”.

[Wardani and Rumiyatun, 2017] mengemukakan bahwa samsat drive thru berpengaruh positif terhadap kepatuhan wajib pajak kendaraan bermotor. [Puteri et al., 2019] mengemukakan "Samsat drive thru berpengaruh negative dan tidak signifikan terhadap kepatuhan wajib pajak" 


\section{E-Samsat}

Suatu bentuk pelayanan yang dilakukan Samsat dengan melakukan pembayaran Pajak Kendaraan bermotor menggunakan Alat elektronika seperti ATM (Wardani dan Fiktri, 2018).

[Wardani and Juliansya, 2018], melakukan penelitian bahwa program e-samsat berpengaruh positif terhadap kepatuhan wajib pajak kendaraan bermotor karena dinilai efektif dan efisien dalam memberikan kemudahan kepada wajib pajak kendaraan bermotor dalam melakukan pembayaran pajak.

Berdasarkan teori tersebut, maka kerangka pemikiran dan hipotesis penelitian ini adalah:

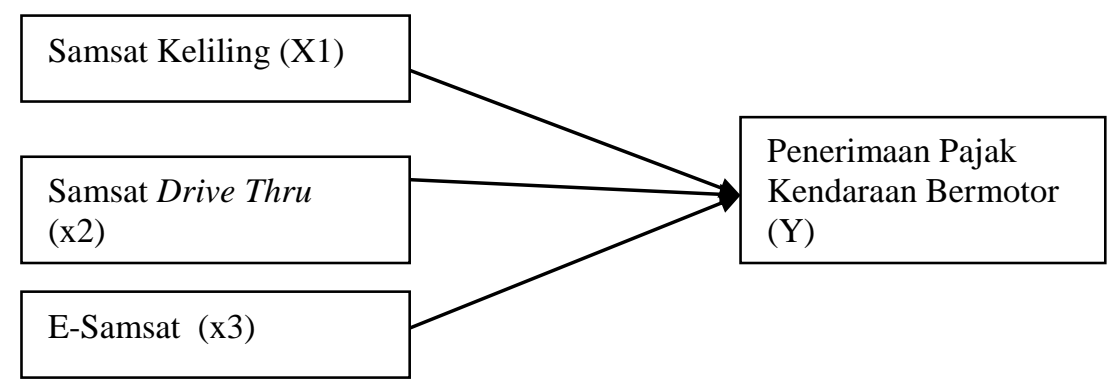

Gambar 1. Kerangka Pemikiran

Hipotesis Pengaruh Parsial Samsat Keliling, Samsat Drive Thru, E-Samsat terhadap penerimaan Pajak di Kantor Samsat Jakarta Timur

$\mathrm{H}_{1}=$ Ada Pengaruh signifikan antara Samsat Keliling terhadap penerimaan Pajak di kantor Samsat Jakarta Timur

$\mathrm{H}_{2}=$ Ada Pengaruh signifikan antara Samsat Drive Thru terhadap penerimaan Pajak di Kantor Samsat Jakarta Timur

$\mathrm{H}_{3}=$ Ada Pengaruh signifikan antara E-Samsat terhadap penerimaan Pajak di Kantor Samsat Jakarta Timur

Hipotesis Pengaruh Simultan Samsat Keliling, Samsat Drive Thru, E-Samsat terhadap penerimaan Pajak di Kantor Samsat Jakarta Timur

$\mathrm{H}_{4}=$ Ada Pengaruh signifikan secara simultan antara Samsat Keliling, Samsat Drive Thru, E-Samsat terhadap penerimaan Pajak di kantor Samsat Jakarta Timur 


\section{Metode Penelitian}

\section{Metode Pengumpulan Data}

Pengumpulan data dalam penelitian ini digunakan metode observasi dimana peneliti melakukan pengamatan langsung terhadap objek penelitian, melakukan wawancara terhadap pihak yang terkait dengan pembahasan penelitian dan melakukan studi pustaka yang berhubungan dengan teori-teori terkait dengan tema penelitian.

\section{Objek Penelitian}

Objek dalam penelitian ini adalah layanan penerimaan pajak kendaraan bermotor di Kantor Samsat Jakarta Timur. Data yang digunakan yaitu data penerimaan pajak kendaraan bermotor dari layanan samsat keliling, Drive Thru, layanan E-samsat dan total penerimaan pajak bulan juni 2016 sampai dengan bulan juli 2018 di Samsat Administrasi Jakarta Timur.

\section{Metode Analisis Data}

Metode analisis yang digunakan adalah diskriptif kuantitatif. Menurut [A. Muri, 2017] penelitian deskriptif kuantitatif adalah salah satu jenis penelitian yang bertujuan mendeskripsikan secara sistematis, faktual, dan akurat mengenai fakta dan sifat populasi tertentu, atau mencoba menggambarkan fenomena secara detail. Peneliti melakukan uji hipotesis pengaruh secara parsial dan simultan penerimaan pajak dari SAMSAT Keliling, Samsat Drive-Thru, E-Samsat Terhadap Penerimaan Pajak Kendaraan Bermotor di Kantor Samsat Jakarta Timur dengan analisis regresi linier berganda. Variabel independent dalam penelitian ini $\mathrm{x}_{1}$ yaitu Samsat Keliling, $\mathrm{X}_{2}$ yaitu Samsat Drive Thru dan $\mathrm{x}_{3}$ E-Samsat sedangkan variabel y nya penerimaan pajak kendaraan bermotor. Data-data penelitian tersebut sebelum dilakukan uji hipotesis dilakukan uji asumsi klasik seperti uji normalitas, heterokadisitas, linieritas dan multikolineritas terdahulu dan diolah menggunakan softwere SPSS versi 21.

\section{Hasil dan Pembahasan}

\subsection{Data penelitian}

Data yang digunakan dalam penelitian adalah data penerimaan pajak dari SAMSAT Keliling (X1), Samsat Drive-Thru (x2), E-Samsat(x3) dan total Penerimaan Pajak Kendaraan Bermotor (Y) di Kantor Samsat Jakarta Timur periode juni 2016 sampai juli 2018. Adapun data yang sudah disederhanakan sebagai berikut: 
Tabel 1. data penerimaan pajak dari layanan Samsat Kantor Samsat Jakarta Timur bulan juni 2016-juli 2018

\begin{tabular}{|c|c|c|c|c|c|}
\hline TAHUN & & $\begin{array}{l}\text { SAMSAT } \\
\text { KELILING }\end{array}$ & $\begin{array}{l}\text { SAMSAT } \\
\text { DRIVE-THRU }\end{array}$ & $\begin{array}{l}\text { E- } \\
\text { SAMSAT }\end{array}$ & $\begin{array}{l}\text { PENERIMAAN } \\
\text { PKB }\end{array}$ \\
\hline & JUNI & 21,63 & 20,95 & 15,74 & 25,55 \\
\hline & JULI & 21,34 & 20,75 & 16,12 & 25,17 \\
\hline & AGUSTUS & 21,50 & 20,97 & 15,00 & 25,49 \\
\hline & SEPTEMBER & 22,37 & 20,98 & 15,54 & 25,41 \\
\hline & OKTOBER & 21,68 & 21,59 & 16,76 & 25,51 \\
\hline & NOVEMBER & 21,56 & 21,76 & 00,00 & 25,57 \\
\hline & DESEMBER & 21,71 & 21,80 & 16,86 & 25,57 \\
\hline \multirow[t]{12}{*}{2017} & JANUARI & 21,79 & 21,99 & 17,04 & 25,62 \\
\hline & FEBRUARI & 21,61 & 21,73 & 18,11 & 25,47 \\
\hline & MARET & 22,23 & 21,92 & 18,09 & 25,67 \\
\hline & APRIL & 21,76 & 21,82 & 17,16 & 25,55 \\
\hline & MEI & 21,78 & 22,00 & 18,85 & 25,72 \\
\hline & JUNI & 21,72 & 21,83 & 18,36 & 25,56 \\
\hline & JULI & 21,80 & 22,01 & 18,90 & 25,66 \\
\hline & AGUSTUS & 21,89 & 22,20 & 19,55 & 25,87 \\
\hline & SEPTEMBER & 21,71 & 21,98 & 19,52 & 25,49 \\
\hline & OKTOBER & 21,75 & 22,06 & 19,52 & 25,54 \\
\hline & NOVEMBER & 21,73 & 21,96 & 19,03 & 25,51 \\
\hline & DESEMBER & 21,84 & 21,98 & 19,55 & 25,65 \\
\hline \multirow[t]{7}{*}{2018} & JANUARI & 21,86 & 22,14 & 19,38 & 25,60 \\
\hline & FEBRUARI & 21,52 & 21,87 & 19,09 & 25,48 \\
\hline & MARET & 21,86 & 22,01 & 19,40 & 25,67 \\
\hline & APRIL & 21,83 & 21,95 & 18,99 & 25,61 \\
\hline & MEI & 22,01 & 22,05 & 19,80 & 25,66 \\
\hline & JUNI & 21,71 & 21,99 & 19,51 & 25,33 \\
\hline & JULI & 21,95 & 22,19 & 19,61 & 25,82 \\
\hline
\end{tabular}

Sumber: Data Olahan

Dari data tabel 1. penerimaan pajak layanan yang dilakukan oleh Samsat Kantor Samsat Jakarta Timur dilakukan uji asumsi klasik dengan hasil sebagai berikut:

1. Uji Normalitas

Menurut [Ghozali, 2016], uji normalitas dilakukan untuk menguji apakah dalam model regresi variabel independen dan variabel dependen atau keduanya mempunyai distribusi normal atau tidak. Untuk pengujian ini bisa digunakan uji one sample kolmogorov-smirnov. Jika Hasil diatas 0,05 maka berdistribusi normal, jika dibawah 0,05 maka data berdistribusi tidak normal. Uji one sample 
kolmogorov-smirnov Test diperoleh hasil asymp sig (2-tailed) sebesar 0,608. Hasil test sebesar 0,608 diatas 0,05 sehingga dapat disimpulkan bahwa data berdistribusi normal.

2. Uji Heterokadisitas

Dengan diagram scater plot dilihat bahwa titik-titik menyebar dan tidak membentuk pola tertentu sehingga dapat disimpulkan bahwa data tidak terjadi gejala heterokadisitas.

3. Uji multikolinieritas

Menurut [Ghozali, 2016] pengujian multikolinearitas bertujuan untuk menguji apakah model regresi ditemukan adanya korelasi antar variabel bebas (independen). Jika nilai tolerance lebih besar dari 0,10 dan VIF kurang dari 10, maka tidak terjadi gejala multikolinieritas. Hasil dari pengolahan SPSS versi 21 untuk Colinearity Statistics diperoleh Nilai Tolerance Samsat Keliling sebesar 0,892, Samsat Drive Thru sebesar 0,842 dan E-Samsat sebesar 0,853. Sedangkan nilai VIF untuk Samsat Keliling 1,121, Samsat Drive Thru sebesar 1,187 dan ESamsat 1,172. Dari hasil tersebut disimpulkan bahwa nilai Toleransi diatas 0,10 dan nilai VIF kurang dari 10 sehingga penelitian ini tidak terdapat gejala multikolinieritas

4. Uji Linieritas

Berdasarkan hasil dari SPSS yang menggambarkan plot antara nilai residu (ZRESID) dengan nilai prediksi (ZPRED) pada model regresi berganda, sehingga diperoleh hasil bahwa model telah linier karena nilai residu yang mengikuti alur residu normal.

3.2. Pengaruh Samsat Keliling Terhadap Penerimaan Pajak di Kantor Samsat Jakarta Timur

Tabel 2. koefisien

\begin{tabular}{|c|c|c|c|c|c|c|}
\hline \multicolumn{7}{|c|}{ Coefficients ${ }^{\text {a }}$} \\
\hline \multirow[t]{2}{*}{ Model } & & $\begin{array}{l}\text { Standai } \\
\text { Coeffici }\end{array}$ & $\begin{array}{l}\text { dized } \\
\text { ents }\end{array}$ & $\begin{array}{c}\text { Standardized } \\
\text { Coefficients }\end{array}$ & $\mathrm{t}$ & Sig. \\
\hline & B & & Std. Error & Beta & & \\
\hline 1 (Constant) & 16,538 & 2,346 & & & 7,049 & 0,000 \\
\hline Samsat Keliling & 0,209 & 0,106 & & 0,313 & 1,973 & 0,061 \\
\hline Samsat Drive & 0,209 & 0,057 & & 0,597 & 3,658 & 0,001 \\
\hline
\end{tabular}




\begin{tabular}{ccccccc}
\hline Thru & & & & & \\
\hline E-Samsat & $-0,004$ & 0,006 & $-0,117$ & $-0,719$ & 0,480 \\
\hline
\end{tabular}

a Dependent Variable: Penerimaan PKB sumber: Data olahan dengan SPSS

Hipotesa yang terbentuk secara parsial Pengaruh antara Samsat Keliling Terhadap Penerimaan Pajak di Kantor Samsat Jakarta Timur adalah:

$\mathrm{HO}_{1}=$ Tidak ada pengaruh pengaruh signifikan antara Samsat Keliling terhadap penerimaan Pajak di Kantor Samsat Jakarta Timur $\mathrm{H}_{1}=$ Ada Pengaruh signifikan antara Samsat Keliling terhadap penerimaan Pajak di Kantor Samsat Jakarta Timur

Berdasarkan table 2. Hasil pengujian hipotesa menunjukkan tingkat signifikansi sebesar 0,061, nilai signifikansi 0,061>0,05 berarti $\mathrm{H}_{1}$ diterima, $\mathrm{H}_{1}$ ditolak, sehingga dapat disimpulkan di periode juni 2016-juli 2018 tidak terdapat pengaruh yang signifikan antara penerimaan pajak samsat keliling terhadap penerimaan pajak kendaraan bermotor di Kantor Samsat Jakarta Timur. Layanan di Samsat Kantor Samsat Jakarta Timur bermacam-macam, sehingga masyarakat dapat memilih bentuk layanan yang diminati. Jika dilihat dari hasil penelitian tidak terdapat pengaruh yang signifikan maka layanan samsat keliling ini memberikan kontribusi tidak terlalu besar terhadap penerimaan pajak kendaraan motor pada wilayah tersebut. Seperti yang dikemukakan dalam Penelitian [Rohemah et al., 2016] yang menyatakan bahwa” Layanan Samsat keliling akses dan complain center berpengaruh terhadap kepatuhan wajib pajak, sedangkan fasilitas dan website tidak berpengaruh terhadap kepatuhan wajib pajak". Hasil penelitian menyatakan bahwa beberapa jenis layanan yang termasuk samsat keliling berpengaruh terhadap kepatuhan wajib pajak. Efek dari kepatuhan wajib pajak akan meningkatkan hasil penerimaan Pajak Kendaraan Bermotor.

\subsection{Pengaruh Samsat Drive Thru Terhadap Penerimaan Pajak di Kantor} Samsat Jakarta Timur

Hipotesa yang terbentuk secara parsial Pengaruh antara Samsat Drive Thru Terhadap Penerimaan Pajak di Kantor Samsat Jakarta Timur adalah: 
$\mathrm{HO}_{2}=$ Tidak ada pengaruh pengaruh signifikan antara Samsat Drive Thru terhadap penerimaan Pajak di Kantor Samsat Jakarta Timur

$\mathrm{H}_{2}=$ Ada Pengaruh signifikan antara Samsat Drive Thru terhadap penerimaan Pajak di Kantor Samsat Jakarta Timur

Berdasarkan table 2. Hasil pengujian hipotesa menunjukkan tingkat signifikansi sebesar 0,001 , nilai signifikansi $0,001<0,05$ berarti $\mathrm{H}_{2}$ ditolak, $\mathrm{H}_{2}$ diterima, sehingga dapat disimpulkan di periode juni 2016-juli 2018 ada pengaruh yang signifikan antara penerimaan pajak samsat Drive Thru terhadap penerimaan pajak kendaraan bermotor di Kantor Samsat Jakarta Timur. Layanan bentuk Samsat Drive Thru Sangat diminati oleh masyarakat pemilik kendaraan bermotor khususnya di Kantor Samsat Jakarta Timur karena praktis dan masyarakat dalam membayar pajak tidak perlu turun dari kendaraannya. Hal ini sesuai dengan penelitian [Waqiah (2017] yang menyatakan bahwa layanan samsat drive thru memberikan pengaruh kontribusi yang signifikan terhadap penerimaan pajak asli Daerah. Sejalan juga dengan penelitian yang dilakukan [Wardani and Rumiyatun, 2017] mengemukakan bahwa samsat drive thru berpengaruh positif terhadap kepatuhan wajib pajak kendaraan bermotor. Tetapi berbeda dengan penelitian [Puteri et al., 2019] yang menyatakan bahwa samsat drive thru berpengaruh negative dan tidak signifikan terhadap kepatuhan wajib pajak, hal ini disebabkan perbedaan kondisi dan karakteristik wilayahnya.

\subsection{Pengaruh E-Samsat Terhadap Penerimaan Pajak di Kantor Samsat Jakarta} Timur

Hipotesa yang terbentuk secara parsial Pengaruh antara E-Samsat Terhadap Penerimaan Pajak di Kantor Samsat Jakarta Timur adalah:

$\mathrm{H}_{3}=$ Tidak ada pengaruh pengaruh signifikan antara E-Samsat terhadap penerimaan Pajak di Kantor Samsat Jakarta Timur

$\mathrm{H}_{3}=$ Ada Pengaruh signifikan antara E-Samsat terhadap penerimaan Pajak di Kantor Samsat Jakarta Timur

Berdasarkan tabel 2. Hasil pengujian hipotesa menunjukkan tingkat signifikansi sebesar 0,480 , nilai signifikansi $0,480>0,05$ berarti $\mathrm{H}_{3}$ diterima, $\mathrm{H}_{3}$ ditolak, sehingga dapat disimpulkan di periode juni 2016-juli 2018 tidak terdapat pengaruh yang signifikan antara penerimaan pajak e-samsat terhadap 
penerimaan pajak kendaraan bermotor di Kantor Samsat Jakarta Timur. Layanan ini belum memberikan konstribusi yang signifikan terhadap penerimaan pajak kendaraan di Kantor Samsat Jakarta Timur karena masyarakat lebih cenderung memilih yang lebih praktis seperti layanan drive thru. Berbeda dengan penelitian [Wardani and Juliansya, 2018] mengemukakan bahwa layanan e-samsat berpengaruh positif terhadap kepatuhan wajib pajak kendaraan bermotor karena dinilai efektif dan efisien dalam memberikan kemudahan kepada wajib pajak kendaraan bermotor dalam melakukan pembayaran pajak. Hal ini disebabkan perbedaan gaya hidup dan karakteristik masyarakat di wilayah tersebut.

\subsection{Pengaruh Samsat Keliling, Samsat Drive Thru dan E-Samsat Terhadap Penerimaan Pajak di Kantor Samsat Jakarta Timur}

Tabel 3. uji Anova

\begin{tabular}{|c|c|c|c|c|c|c|}
\hline & \multicolumn{6}{|c|}{ ANOVA $^{\mathrm{a}}$} \\
\hline & Model & Sum of Squares & df & Mean Square & $\mathrm{F}$ & Sig. \\
\hline 1 & Regression & 0,256 & 3 & 0,085 & 7,516 &, $001^{b}$ \\
\hline & Residual & 0,25 & 22 & 0,011 & & \\
\hline & Total & 0,506 & 25 & & & \\
\hline
\end{tabular}

a Dependent Variable: Penerimaan PKB

b Predictors: (Constant), E-Samsat, Samsat Keliling, Samsat Drive Thru

Sumber : Data olahan dengan SPSS

Hipotesa yang terbentuk secara simultan Pengaruh antara Samsat Keliling, Samsat Drive Thru dan E-Samsat Terhadap Penerimaan Pajak di Kantor Samsat Jakarta Timur adalah:

$\mathrm{HO}_{4}=$ Tidak ada pengaruh secara simultan antara Samsat Keliling, Samsat Drive

Thru dan E-Samsat terhadap penerimaan Pajak di Kantor Samsat Jakarta Timur

$\mathrm{H}_{4}=$ Ada Pengaruh signifikan pengaruh secara simultan antara Samsat Keliling, Samsat Drive Thru dan E-Samsat terhadap penerimaan Pajak di wilayah Jakarta Timur 
Berdasarkan Hasil uji hipotesa dengan menggunakan SPSS dalam model Summary menunjukkan tingkat signifikan sebesar 0,001 . Hal ini berarti 0,001 lebih kecil dari pada 0,05 sehingga $\mathrm{H}_{4}$ di tolak dan $\mathrm{H}_{4}$ diterima disimpulkan bahwa Penerimaan Pajak dari Samsat Keliling, Samsat Drive Thru secara silmutan atau bersama-sama dan signifikan mempengaruhi penerimaan pajak kendaraan bermotor di Kantor Samsat Jakarta Timur.

\section{Kesimpulan}

Berdasarkan Hasil penelitian dapat disimpulkan bahwa secara parsial variabel Samsat Drive Thru mempunyai pengaruh yang signifikan terhadap penerimaan pajak kendaraan bermotor di wilayah Jakarta Timur, sedangkan secara parsial variabel Samsat Keliling dan E-Samsat tidak mempunyai pengaruh secara signifikan terhadap pajak kendaraan bermotor di Kantor Samsat Jakarta Timur. Sedangkan secara simultan ketiga variabel Samsat Keliling, Samsat Drive Thru dan E-Samsat mempunyai pengaruh signifikan terhadap pajak kendaraan bermotor Pada di Kantor Samsat Jakarta Timur. Layanan yang dilakukan oleh Kantor Samsat Kantor Samsat Jakarta Timur bermacammacam sehingga masyarakat pun dapat memilih layanan pembayaran yang sesuai, dari penelitian kecenderungan masyarakat lebih memilih layanan Drive Thru dikarenakan lebih praktis.

Penelitian ini masih terbatas pada pengaruh layanan samsat keliling, samsat Drive Thru dan E-Samsat terhadap penerimaan pajak kendaraan bermotor di kantor Samsat Kantor Samsat Jakarta Timur, sedangkan layanan samsat bermacam-macam sehingga diharapkan objek untuk penelitian selanjutnya dapat membahas ruang lingkup lebih luas dan dikembangkan lebih lanjut.

\section{Referensi}

A. Muri Y. 2017. 2. Penelitian Deskriptif Kuantitatif. In: Metode Penelitian Kuantitatif, Kualitatif \& Penelitian Gabungan.

Ghozali I. 2016. Aplikasi Analisis Multivariate dengan Program IBM SPSS 21 :Update PLS Regresi. Semarang.

Mawardi L. 2011. Optimalisasi Samsat Drive Thru Guna Mewujudkan Pelayanan Prima dalam Rangka Mendukung Transparansi Pelayanan POLRI pada Kantor Bersama 
SAMSAT Jakarta Selatan.

Puteri PO, Syofyan E, Mulyani E. 2019. Analisis Pengaruh Sanksi Administrasi, Tingkat Pendapatan, Dan Sistem Samsat Drive Thru Terhadap Kepatuhan Wajib Pajak Kendaraan B (Studi Kasus Kantor Samsat Kota Padang). J. Eksplor. Akunt. Rohemah R, Kompyurini N, Rahmawati E. 2016. Analisis Pengaruh Implementasi Layanan Samsat Keliling Terhadap Kepatuhan Wajib Pajak Kendaraan Bermotor Roda Dua Di Kabupaten Pamekasan. J. InFestasi.

Undang-Undang Republik Indonesia Nomor 28 Tahun 2009. 2009.

Waqidah LR. 2017. Kontribusi penerimaan pajak kendaraan bermotor (pkb) dari layanan drive thru terhadap pendapatan asli daerah (pad) di kabupaten madiun.

Wardani DK, Juliansya F. 2018. Pengaruh Program E-Samsat Terhadap Kepatuhan Wajib Pajak Kendaraan Bermotor Dengan Kepuasan Kualitas Pelayanan Sebagai Variabel Intervening (Studi Kasus Samsat Daerah Istimewa Yogyakarta). J. Akunt. Manaj. Akmenika.

Wardani DK, Rumiyatun R. 2017. PENGARUH PENGETAHUAN WAJIB PAJAK, KESADARAN WAJIB PAJAK, SANKSI PAJAK KENDARAAN BERMOTOR, DAN SISTEM SAMSAT DRIVE THRU TERHADAP KEPATUHAN WAJIB PAJAK KENDARAAN BERMOTOR. J. Akunt.

Yesserie. 2015. Peraturan Presiden Republik Indonesia Nomor 5. Nhk技研 151: 10-17. Yusuf M. 2017. Metode Penelitian Kuantitatif, Kualitatif \& Penelitian Gabungan, Pertama. Jakarta: Kencana. 480 p. 